\title{
Making Sense of Psalm 127:3-5 in African / South African Contexts
}

\author{
Madipoane Masenya (NgWan’a MPhahlele) \\ (UNIVERSITY OF SOUTH AFRICA)
}

\begin{abstract}
African wisdom sayings have enjoyed and continue to enjoy some authoritative status in varying African contexts from time immemorial till today. As sacred texts, African proverbs have shaped and continue to shape, whether consciously or not, the worldview of African peoples, even in present day contexts. The holistic worldview which embeds Ps 127:3-5, one that underlies many an African proverb, reveals the great store set by large families and the celebration of women's role as mothers in both contexts. The main question that this article seeks to engage is: If read from an (African) South African context, which insights may emerge from Ps 127:3-5?
\end{abstract}

KEYWORDS: Psalm 127:3-5; optimistic simplistic worldview, holistic, man, sons, mother, Israel, Africa.

\section{A INTRODUCTION}

That the Israelite worldview as embedded in some Old Testament texts reveals apparent resemblances with (an) African worldview(s) has been attested to by various scholars. ${ }^{1}$ In both the Israelite and African contexts, for example, the compartmentalization of life into the economic, political, social and religious

* Article submitted: 2019/03/04; peer reviewed: 2019/05/18; accepted: 2019/07/16. Madipoane Masenya (Ngwan'a Mphahlele), "Making Sense of Psalm 127:3-5 in African / South African Contexts," OTE 32 no. 2 (2019): 412-425. DOI: https://doi.org/ $10.17159 / 2312-3621 / 2019 / v 32 n 2 \mathrm{a} 9$.

1 Jasper J. Burden and Hendrik L. Bosman. Only Guide for OTB302-3 (Pretoria: University of South Africa, 1982); Masenya, Madipoane J. In the School of Wisdom: An Interpretation of Some Old Testament Proverbs in a Northern Sotho Context (Unpublished Master of Arts Dissertation; Pretoria: University of South Africa, 1989); Lechion P. Kimilike. Poverty in the Book of Proverbs: An African Transformational Hermeneutic of Proverbs on Poverty (Bible and Theology in Africa 7; New York, NY: Peter Lang, 2008); Friedeman W. Golka. The Leopard's Spots: Biblical and African Wisdom in Proverbs (Edinburgh: T\&T Clark, 1993); Madipoane Masenya (Ngwan'a Mphahlele), How Worthy is the Woman of Worth? Rereading Proverbs 31:10-31 in African-South Africa (Bible and Theology in Africa 4; New York: Peter Lang, 2004); Dorothy BEA Akoto-Abutitate, Proverbs and the African Tree of Life: Grafting Biblical Proverbs on to Ghanaian Eve Folk Proverbs (Studies in Systematic Theology 16; Leiden: Brill, 2014). 
aspects among others, is denied because the whole is viewed as religious. ${ }^{2}$ In other words, in both contexts, there is a holistic religious worldview on life. When Ps 127:3-5 is read through the lens of selected African proverbs, such a holistic worldview becomes apparent. Within the preceding worldview, it seems that in both contexts, there is a great store set by large families and the celebration of women's motherhood role. Using selected African (South African) ${ }^{3}$ proverbs as hermeneutical lenses, an attempt will be made at the rereading of Ps 127:3-5 with the following main objective: If Ps 127:3-5 is read side by side with selected African proverbs, which insights may emerge - especially about the notion of family and/or motherhood - from both the Israelite and African contexts? The following themes will be used to engage the contents of this article: 1) African proverbs as sacred/ authoritative texts, 2) a simplistic optimistic worldview?, 3) the whole is religious and, 4) a window into notions of masculinities then?

\section{B TEXT AND TRANSLATION}

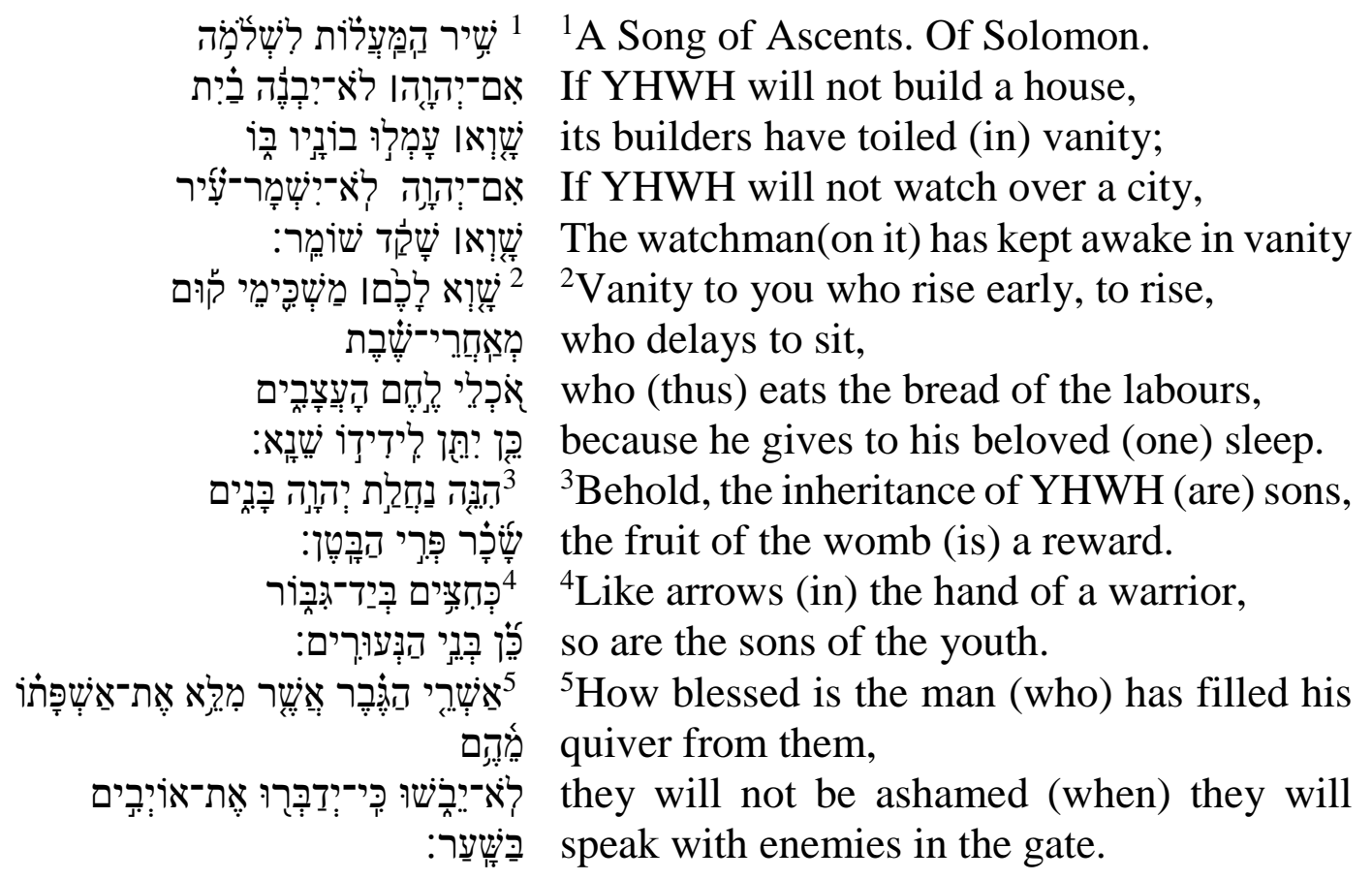

2 Madipoane Masenya (Ngwan'a Mphahlele), “The Use of the Bible Regarding Poverty in African-South African Pentecostal Settings: A Bosadi (Womanhood) Approach," in Religion and Poverty: Pan African Perspectives (ed. Peter P. Paris; Durham, NC: Duke University Press, 2009), 152-165.

3 The phrase African/South African as used in the present article should be understood in a twofold way: first, as denoting (an) African context/proverb(s) in South Africa; second as depicting an African context/proverbs elsewhere on the African continent. As the author is located within an African-South African context, the main African proverb that forms the pivot around which the discussion in this text rotates, is the Northern Sotho proverb. 


\section{AFRICAN PROVERBS AS SACRED / AUTHORITATIVE TEXTS}

African oral texts (read: proverbs), appear to derive their authority from their links with the ancestors and/or (the) elders. The following Northern Sotho phrase, mogologolo o boletše a re, literally translated as "the ancestor has said", can serve as a case in point. ${ }^{4}$ The phrase is strategically mentioned before a proverb is uttered. In that way, the expression serves to imbue a proverb with some form of authority as the utterer (read: mogologolo), no longer forms part of the living, while the elders, i.e., the ancestors/living dead (so John Mbiti), ${ }^{5}$ are held in great esteem as sacred figures within the African religio-cultural contexts. ${ }^{6}$ The Northern Sotho proverb, lentšu la mohu ga le tshelwe, literally, "a word of the deceased cannot be transgressed," gives the reader a glimpse on the high esteem which is bestowed on the deceased as well as the authority of the deceased's words in the preceding African-South African context. The proverb also brings to light the oral nature of African people. The word lentšu, literally "a word/voice," which cannot be transgressed, was not the written word. It was, like all African proverbs, an oral word. S.B. Nkesiga thus rightly argues: "In a popular proverb, we learn how the elders were the 'wisdom texts' of proverbs in the African oral tradition." Despite the highly Westernised signs visible in many an African context, ${ }^{8}$ the authority still invested in many an African wisdom text seems to remain entrenched, whether consciously or unconsciously, in people's minds, hence the saying that one can remove an African from Africa but one cannot remove one's Africanness from him/her despite her/his location on the globe.

The following Northern Sotho proverb, which is central to the argument in this article, can serve as a case in point: $A$ ba tswalwe, ba ate, monalepelo ga a tsebje. ${ }^{9}$ Its literal translation is, "Let them be birthed, and (let them) increase,

4 See also S. B. Nkesiga. Virtuous Living: Toward an African Theology of Wisdom in the Context of the African Renaissance (Ph.D. thesis; Port Elizabeth: Nelson Mandela Metropolitan University, 2005).

5 John S. Mbiti. African Religions and Philosophy (London: Heinemann, 1969), 130.

6 Madipoane Masenya (Ngwan'a Mphahlele), "Ruling From Their Graves? Reading Naomi within the African Religio-Cultural Context," in The Five Scrolls (ed. Athalya Brenner-Idan et al.; Texts @ Contexts 6; London: T\&T Clark, 2018), 3-14; see also Oliver K. Matsepe. Kgati ya Moditi (Pretoria: Van Schaik), 1974.

7 S. B. Nkesiga, Virtuous Living, 255.

8 See in particular the fast-growing urban populations in varying African contexts, including the African-South African context; see Kopano Ratele, Liberating Masculinities (Cape Town: HSRC, 2016).

9 J. R. D. Rakoma. Marema-ka-Dika Tša Sesotho sa Leboa. (Pretoria: Van Schaik, 1971), 107. The following proverb cited by Mercy Amba Oduyoye, the mother of African women's theology, also captures this celebrated role of women as mothers in various African sayings: "The tortoise has no breasts and yet feeds her young ones." 
because the one with a long heart is not known." The proverb's tenor reveals that in African cultures, families with many children would be/are preferred to those with fewer or no children. In such cultures, it is thus taboo for married couples not to have children. ${ }^{10}$ Children are regarded as a heritage that each "normative" family ought to have. The authority embedded in the preceding proverb cannot be questioned, hence the different measures which would be taken to rectify the apparent challenges of barrenness and/or sterility in such contexts. ${ }^{11}$ In varying African contexts, the existence of many children would be, and still is, regarded as a sign of approval by the Sacred Other and/or the ancestors. The motherhood role of a woman is thus highly celebrated in these cultures. Does it occasion any surprise then that the following Yorùbá proverb, Òrișà bí ìyá kò sí. İyá là bá má a bo comes so close to deifying a woman as a mother? ${ }^{12}$ The tenor of the proverb reveals that there is no deity like (a) mother, a mother is worthy of being worshipped!

Unlike African proverbs which did not undergo the process of canonisation like in the case of biblical books, present day African readers of Ps 127:3-7 read it as a text which has already been canonised. The Bible still enjoys some status as an authoritative text in many an African context. ${ }^{13}$ Fundamentalist, women-unfriendly interpretations of the Old Testament will usually declare that that which is canonical, has to be obeyed unquestionably. In the same way, the authority of African proverbs is taken for granted. Especially

Mercy A. Oduyoye. Daughters of Anowa: African Women and Patriarchy (Maryknoll, NY: Orbis, 1995), 59.

10 Hence Mbiti, African religions, 130 can argue: "Biologically both husband and wife are reproduced in their children, thus perpetuating the chain of humanity. In some societies it is believed that the living dead are re-incarnated in part, so that aspects of their personalities or physical characteristics are 're-born' in their descendants. A person who, therefore, has no descendants in effect quenches the fire of life, and becomes forever dead since his line of physical continuation is blocked if he does not get married and have children" (emphasis: author's).

11 Worthy of note (cf. also in the Israelite context), the culprit to be blamed for a specific family's lack of children or even when children belonged to the same sex, especially the female sex, would be women.

12 Funlola, Oduyoye, "(Un)popular Images of Women in Yoruba Popular Culture: A Quest for Human Dignity," in Sacred Selves: Essays on Gender, Religion and Popular Culture (ed. Juliana Claassens and Sylvia Viljoen; Cape Town: Griffel, 2012), 187-205. 13 See the popularity of the Old Testament in particular, especially in the various contexts of the African Independent Churches; see Philomena N. Mwaura, "The Old Testament in the Nabii Christian Church of Kenya," in Interpreting the Old Testament in Africa: Papers from the International Symposium on Africa and the Old Testament in Nairobi, October 1999 (ed. Mary N. Getui et al.; Bible and Theology in Africa 2; New York, NY: Peter Lang, 2001), 165-169; Musa W. Dube, "Consuming a Colonial Bomb: Translating Badimo into 'Demons' in the Setswana Bible Translation (Matthew 8:28-34; 15”22),” JSNT 73 (1999): 33-59. 
in settings where the authority of both texts (the biblical text and the African proverb) remains basically unquestioned, the resultant product may not always be palatable, especially for those who sit on the margins of the interpretative process. The preceding fact will become clearer as the present discussion unfolds.

In light of the preceding discussion, the celebration of a family with many sons as it appears to be the case in Ps 127:3-7, as well as the blessings linked with such a family, will make perfect sense within African patriarchal cultures. As a matter of fact, in the preceding cultures, the societal pressure to have (many) children could be felt not only by women, but also by men. ${ }^{14}$ Likewise, the mood of the text of our investigation seems to reveal that even the men in the context of the psalm's production may have suffered such societal pressure. ${ }^{15}$ It thus appears that an Israelite man's masculinity was determined and boosted by among others, the number of sons which his family possessed. Although at the core of the blessing attached to the celebration of a large family is the work of an efficient female womb, that is the celebration of women's motherhood role, the feminine (read: woman) is conspicuous by its absence in the text of our investigation.

Within our changing African contexts, though contexts characterised by, among others, the pervasive impact of the West (and its individualistic culture, see also, as already noted with Ratele, the fast-growing urban populations in Africa), limited resources, the harsh reality of the African continent ranking among the poorest continents globally (not least because of the haunting legacies of colonialism and apartheid-neo-liberal capitalism for example), the ecological crisis hitting the hardest on the poorest sectors of the globe, the benefits of planning in favour of bigger families have become relatively minimal. The words of Habtu Tewoldemedhim are thus on target:

We need to remember that in the psalmist times many children died in early childhood from the ravages of disease, as well as from the effects of war. It was a blessing indeed if parents were able to have a large family. Now many of our countries fear overpopulation, and we

14 In a discussion session from one of the sessions of the Pan-African Seminar on Religion and Poverty in Ocho Rios, Jamaica in 2003, Professor Laurenti Magesa, a Roman Catholic father, hinted at one's bias towards women on the preceding point. He noted that there is equally a bias against men who do not have children in African contexts.

15 For example, if we read the second stichos of Ps 127:3 as "the fruit of the body" rather than the restrictive "fruit of the womb", the preceding argument may hold water even here. 
also have to think about how many children we can care for, educate and prepare for life. ${ }^{16}$

Despite the cultural, chronological, and linguistic gap between the cultural world which produced the Old Testament and the African world(s), cultural relativity enables us to argue that contextualization between two different contexts is possible. Statements from one context (cf. the Israelite context as reflected in Ps 127:3-7), if uttered in a different context (cf. the African [South African] one), can still make sense in the latter context. ${ }^{17}$ Both the Israelite and African worldviews as revealed from the texts under discussion, that is, Ps 127:3-7 and selected African proverbs, appear to be simplistic and optimistic. To the preceding aspect, we now turn.

\section{A SIMPLISTIC, OPTIMISTIC WORLDVIEW?}

Some scholars have observed that the worldview which underlies African proverbs reveals some points of resemblance with the worldview within which some of the proverbs in the Hebrew Bible are embedded. Also, there are scholars who have noted the wisdom undertones of Psalm $127 .{ }^{18}$ In their view, the psalm witnesses to the blessing of children and the protection that they would provide against false witnesses at the city gate. To that end, Hans-Winfried Jungling can argue, "The model followed in the development (of Ps 127) is the classical one of retribution that rewards with a numerous and vital posterity." ${ }^{19}$ Burden can thus rightly argue regarding the apparent resemblance between the African and Israelite worldviews:

What is important is not a common cultural milieu or corresponding pivotal points, common customs or even a common belief in a

16 Habtu Tewoldemedhim et al., "Psalms," in Africa Bible Commentary: A OneVolume Commentary Written by 70 African Scholars (ed. Tokunboh Adeyemo; Nairobi: Word Alive, 2006), 605-746 (730).

17 See Masenya, In the School of Wisdom.

18 See Cyril S. Rodd, "Psalms," in The Oxford Bible Commentary (ed. John Barton and John Muddiman; Oxford: Oxford University Press, 2001), 355-404; Carroll Stuhlmueller, "Psalms," in Harper's Bible Commentary (ed. James Luther Mays; San Francisco; CA: Harper \& Row, 1988), 433-494 (489).

19 Hans-Winfried Jüngling, "Psalms" in The International Bible Commentary: A Catholic and Ecumenical Commentary for the Twenty-first Century (ed. William R. Farmer; Collegeville, PA: Liturgical, 1998), 779-859 (852). As noted previously regarding the points of resemblance between the Old Testament and Africa, it comes as no surprise that even the worldview that embeds Ps 127 will resonate with the one which embeds the proverbs under discussion. 
Supreme Being, but rather common elements in their world-view, a relationship of the spirit. ${ }^{20}$

The optimistic, simplistic worldview underlies both the African sayings and the words of the psalmist in Ps 127:3-7. Let us revisit the previously stated expression on the need for large families. The proverb, a ba tswalwe, ba ate, mona-le pelo ga a tsebje, ${ }^{21}$ is cast in the form of a command. Such a form provides no room for deviation from the rule. The motivation behind the command to give birth to many babies also seems to be cast in stone, that is, a child with a long (i.e., kind) heart is unknown. In a nutshell, it is simply assumed that out of the many children who must be born (cf. the authority embedded in the command form), there will, undoubtedly, be one or two (or more) children who will deal kindly with their parents. Within the preceding simplistic, optimistic worldview on life, one in which easy answers were/are provided to life's complex questions, no room was/is given to the harsh reality that out of the many children who must be born to a specific family, there could be no child who is kind-hearted. Equally, room was/is not given to the existence of women and men who, for reasons beyond their control, cannot bear their own biological children. Even in the case of the Akan saying on the supremacy of motherhood, that is, Ena yie "motherhood is supreme", ${ }^{22}$ the readers are supposed to understand the saying as a given. It apparently cannot be otherwise. The preceding "given" provides no room for the existence of bad mothers who are depicted in some African proverbs (cf. the Northern Sotho and Yorùbá proverbs as cases in point). ${ }^{23}$

The foregoing simplistic, optimistic worldview notable in African proverbs also underlies the words of the psalmist in Ps 127. Although the Hebrew word (בן (ב) can also be used in an inclusive way as in bānim (children) of Israel (cf. also the observation that in the plural form, the word - bannim, cf. 127:4b includes both sexes, as also in Ruth 2:21; Job 1:19), ${ }^{24}$ and though the Hebrew פרי בטן "("the fruit of the womb"), which forms a parallel pair with bānim "sons" in the first stichos can be interpreted to mean children (of all sexes), the

20 Jasper J. Burden and Hendrik L. Bosman, Only Guide for OTB302-3 (Pretoria: University of South Africa, 1982), 74.

21 Literally, "Let them be birthed, and increase because the one with a long heart is not known."

22 Oduyoye, Daughters of Anowa, 1994.

23 Madipoane Masenya (Ngwan'a Mphahlele), “A Literary Figure or Patriarchal Reality? Reflections on the 'ěšet hayil in Light of Depictions of Womanhood from Selected Yorùbá and Sotho Proverbs," VeEc 39 (2018), a1861. https://doi.org/10.41 02/ve.v39i1.1861.

24 William L. Holladay, A Concise Hebrew and Aramaic Lexicon of the Old Testament (Leiden: Brill, 1971), 241. 
tone and contents of Ps 127 as a whole, are heavily if not solely, masculine. ${ }^{25}$ According to the psalmist, to possess many sons is necessarily a depiction of the blessings from Yahweh. The righteous (male human being) who would have allowed Yahweh to build his house (Ps 127:1) would necessarily be blessed or rewarded with many sons. According to the worldview depicted by Ps 127 , room is not given for a wicked man who can have a large family (cf. the flourishing of the wicked). What would concern especially present-day female readers of this text, is that there is equally no room given for the risks which were related to child-bearing and mothering, then and now, depending on the context of the readers. Yet Alice Bach reminds us that, "Another silent element is that one in four women in the ancient Near East died in childbirth. To pray to become pregnant was a life threatening wish." 26 It is also taken for granted that the many children (read: sons) born to families will not disappoint their fathers. The children (sons) will of necessity make their father proud as he will surely not be ashamed when he confronts his enemies in the gate. In the preceding space, the sons of the man's youth will fight for him in his old age. In real life, though, such a neatly calculated perspective does not fit. How many righteous women are usually at the receiving end due to the adverse repercussions of patriarchy on their lives? How many (righteous) parents (men and women) suffer the trauma imposed by their children even in their old age? How many (righteous) families, where the couple had been praying for children, still remain childless? The book of Job provides a clear example of the possibility of deviation from the accepted status quo.

The preceding simplistic, optimistic worldview operates within the whole that is religious. To that aspect we now turn.

\section{E THE WHOLE IS RELIGIOUS}

According to the preceding simplistic, optimistic world-view, there is an order which has been set by God/Yahweh for Israel and the Sacred Other and/or ancestors for Africa; an order to which the people should adhere. The harmony between humans and the supernatural (read: obedience) leads to positive rewards while disobedience to the order leads to penalties. As already noted, such a worldview represents a non-problematic view on reality. Also, in both contexts, the whole (cf. the social, economic, legal, and military, among others) is religious. For example, the man who has his quiver full of sons, one who is necessarily blessed, is first and foremost a righteous man. This is the man who has allowed Yahweh to build his house. The religious undertones of the psalm

25 See, Madipoane Masenya (Ngwan'a Mphahlele), “An Eco(bosadi) Reading of Psalm 127," in The Earth Story in the Psalms and the Prophets (ed. Norman C. Habel and Shirley Wurst; Earth Bible 4; Sheffield: Sheffield Academic, 2001), 109-122.

26 Alice Bach, "Introduction," in Women in the Hebrew Bible: A Reader (ed. Alice Bach; New York, NY: Routledge, 1999), xiii-xxvi (xx). 
as a whole, including the episode of our investigation (Ps 127:3-7), are visible right at the opening of the psalm: Yahweh is the one who (must) build the house and (must) guard the city (Ps 127:1). Yahweh is also the one who opens the wombs of the wives of the men who are obedient to Yahweh. Such men are blessed because the sons are a heritage (wealth) to those who possess them. Especially in a patriarchal space, sons are precious as they not only perpetuate the line of a specific man, they will enable him to be successful at the city gates. ${ }^{27}$ The latter space was both political and legal. So, biology, sociology, economics, politics and law are all interwoven in the lives of characters who operate within a religious whole which is either blessed or cursed by Yahweh. A resonating argument can be made regarding the African proverb, a ba tswalwe, ba ate, mona-le pelo ga a tsebje. A family which has many (male) children is assumed to be in tune with the demands of the order set by the ancestors. The expression, "ditlhokwa di letše" means there is peace between a specific family (and/or individual) and the Sacred Other and/or the ancestors). Such a family, it is assumed, had not angered the ancestors by committing certain taboos. Children, especially sons, are valuable also in this space as they perpetuate patrilinearity. As noted with Mbiti, ${ }^{28}$ there is a belief that each new born baby is an ancestor returned. The preceding claim reveals the inter-woven-ness between (female) biology and religion. If the children are female, ${ }^{29}$ the aspect of economics will also feature as the more female children are born into a specific family, the more the possibility of extending the kraals on account of the cattle for the bride price. So, in both the Israelite and African contexts, the compartmentalization of life is denied.

As previously noted, the worldview depicted by Ps 127 displays a masculine tone, the preceding aspect, irrespective of the core feminine issue which is covertly celebrated, that is the motherhood role of women. Which masculinities (and femininities) are visible from our reading of the Ps 127:3-7? To the preceding question we now turn.

\section{F A WINDOW INTO NOTIONS OF MASCULINITIES THEN?}

Susan E. Haddox argues for what others may regard as liberating notions of masculinity. In her view, biblical masculinity is viewed in relation to the favour which God bestows on a specific man, irrespective of his flaws. She reasons, "Perhaps the most useful lesson that we can learn for our own context is that biblical masculinity is not about demonstrating constant supremacy and never

27 For more details on the significance of the city gates in ancient Israel, refer to the article by Joel K.T. Biwul, "What Is He Doing at the Gate?” OTE 29 (2016): 360-369.

28 Mbiti, African Religions, 130.

29 Noteworthy is the fact that in the Northern Sotho proverb (unlike in the episode from Ps 127), the sex of the children is not specified, albeit the patriarchal nature of African cultures would tilt, like that of biblical Israel, towards male babies. 
showing weakness, as masculinity is often understood today. At times biblical men take the dominant role, but sometimes they defer to others, including their wives, and always to God, if they are successful." 30 Approved (biblical) masculinities appear to be the ones that are subordinated to God. From the first two verses of Ps 127, the psalmist foregrounds a man who puts his trust in nothing/nobody else than in God. In people's everyday lives, male human beings are the ones who build houses even as men are expected to protect (their) households and cities. In Ps 127, the preceding male actions are deferred to God rather than to the conventional man. Although Yahweh is presented as a male deity in the Hebrew Bible, the fact that there is a deference of ordinary masculine tasks to the Sacred Other, is worth noting here. Hence, the biblical male celebrated in this psalm neither trusts in his own strength nor in the strength of chariots. He is featured as trusting in God. The words of J. Clinton McCann Jr. seems to resonate with the preceding observation, though from a more generic perspective: "In the final analysis, Psalm 127 functions as an invitation to entrust our lives to God and so not be anxious about our lives, but to pursue God's claim upon us and strive to embody God's will (see Matt 6:25-34)."'31 The man foregrounded in this psalm appears to be heterosexually married. Although there is no mention of a woman, the fruit of whose womb is celebrated here, it can be safely concluded that she is the wife to the righteous man who is featured in the psalm. Could it be, as David Clines has argued, that one of the features of biblical masculinities is a womanless male? ${ }^{32}$

The wife's presence is implicit though, through the mention of the fruit of her womb. The fruit(s) of the womb becomes a reward for the man who subordinates his masculinity by deferring to God. Femininity as a matter of fact makes the contents of this psalm possible, not only given the important role that a woman played as a household manager during the post-exilic period, but also more importantly, due to the role that a woman played through her reproductive capacity as a mother.

Although we agree with Carol Meyers that in ancient Israel, the birth of children would (naturally) have been the source of joy to both parents, including

30 Susan E. Haddox, "Is There a 'Biblical Masculinity'? Masculinities in the Hebrew Bible," WW 36 (2016): 5-14 (13-14).

31 J. Clinton McCann Jr., "The Book of Psalms," in The New Interpreters Bible, Vol. IV (ed. Leander E. Keck; Nashville, TN: Abingdon, 1996), 641-1279 (1199).

32 According to Clines, the following elements typifies manhood in the David story: 1) The fighting male; 2) The persuasive male; 3) The beautiful male; 4) The bonding male; 5) The womanless male; 6) The musical male; see David J. A. Clines, Interested Readers: The Ideology of the Writers and Readers in the Hebrew Bible (Sheffield: Sheffield Academic, 1995), 216-217. 
mothers, the family line which had to be protected and perpetuated was/is male. ${ }^{33}$ The perpetuation of the male line had to happen even at the risk of the deaths of the mothers. Meyers' observation is important here,

...the infant mortality rate was high; as many as half of the children born may have failed to reach adulthood. This means that women had to have almost twice as many pregnancies as the number of children desired....Given the risk of death in childbirth in ancient Israel, as in any pre-modern society, it is no wonder that the estimated life span for women in ancient Israel, based on the analysis of skeletal remains found in tombs or graves, was about thirty years. ${ }^{34}$

As it has become clearer now, the male-oriented tone of Ps 127:3-7 also reveals that the father even more than the mother stands to gain from the possession of sons. As previously noted, the woman (read: mother) is implicitly mentioned through the invaluable organ that she possesses, that is, the womb. The latter is apparently celebrated for its successful fulfilment of the male agenda. Important questions that may be raised here are: Can women (both ancient and modern) be fully human even if they cannot bear children, naturally or by choice? The man who is subordinated to God (read: the righteous man) will of necessity prosper (be happy/blessed) and one of the signs of his prosperity or blessings is the possession of many male babies (read: sons). Worthy of note is that the sons celebrated here are those born at the men's youthful age, when a man's virility would be at its height. Men's virility was one of the features of masculinity then. ${ }^{35}$

\section{G CONCLUSION}

The main question which formed the pivot around which this essay rotated is: If read from an (African) South African context, which insights may emerge from Ps 127:3-5? As a matter of fact, the key African proverb which was used as a hermeneutical lens to engage the episode, Ps 127:3-5, was, a ba tswalwe, ba ate, mo-na-le pelo ga a tsebje. Our discussion up to this point has hopefully revealed the kind of reading which emerges when African proverbs on motherhood are read side by side with the episode of Ps 127:3-5. In both the Israelite and African contexts, a simplistic, optimistic worldview operates within a religious whole in which the compartmentalization of life is denied. In order to be successful (or

33 Carol Meyers, "Everyday Life: Women in the Period of the Hebrew Bible," in The Women's Bible Commentary (ed. Carol A. Newsom and Sharon H. Ringe; Louisville, KY: Westminster John Knox, 1992), 244-251.

34 Meyers, "Everyday Life", 248.

35 The defining characteristics for hegemonic masculinity in the Hebrew Bible in accord with Haddox and Clines are strength, wisdom, persuasiveness; avoidance of association with women, self-control, honour, male bonding, fertility and marriage; see Haddox, "Is there a 'biblical masculinity'?," 5-14; Clines, Interested Readers, 1995. 
blessed [read: have many sons]), human beings (read: men) have to submit to the demands of the order set by Yahweh and/or the ancestors. Large families were/are celebrated in both contexts. Although the feminine is conspicuous by its absence, a woman's motherhood role seems to be celebrated within a patriarchal masculinist context. Hence the foregrounding of the womb is fundamentally done to celebrate the birth of male babies whose existence would basically serve the male agenda. As Cyril S. Rodd has rightly argued, "Sons were important for building up the power and prestige of the family and v. 5 refers to their support in lawsuits which were judged in the city gate. Sons of a man's youth (v.4) would be in their prime when he came to rely on them for their support."36

As both contexts are patriarchal, talk is basically about men and the agenda being served is male-orientated. However, the celebrated masculinities displayed by Ps 127:3-5 are those subordinated to God.

It was fitting that an essay based on a text from the Psalter be dedicated to one of the fine South African Psalter scholars, Professor Phil Botha. As he retires from a formal academic setting, hopefully not from researching, the following key question might be worth pondering: If the masculinities of South African men and boys were to be deferred to the Sacred Other, could the country's present plight of gender-based violence be overcome?

\section{BIBLIOGRAPHY}

Akoto-Abutitate, Dorothy BEA. Proverbs and the African Tree of Life: Grafting Biblical Proverbs on to Ghanaian Eve Folk Proverbs. Studies in Systematic Theology 16. Leiden: Brill, 2014.

Bach, Alice. "Introduction." Pages xiii-xxvi in Women in the Hebrew Bible: A Reader. Edited by Alice Bach. New York, NY: Routledge, 1999.

Biwul, Joel, K.T. "What Is He Doing at the Gate?" Old Testament Essays 29 (2016): 360-369.

Burden, Jasper J. and Hendrik L. Bosman. Only Guide for OTB302-3. Pretoria: University of South Africa. 1982.

Clines, David J. A. Interested Readers: The Ideology of the Writers and Readers in the Hebrew Bible. Sheffield: Sheffield Academic, 1995.

Dube, Musa W. "Consuming a Colonial Bomb: Translating Badimo into 'Demons' in the Setswana Bible Translation (Matthew 8:28-34; 15:22)". Journal for the Study of the New Testament 73 (1999): 33-59. https://doi.org/10.1177/2F0142064X9 902107303.

Friedeman W. Golka. The Leopard's Spots: Biblical and African Wisdom in Proverbs. Edinburgh: T\&T Clark, 1993.

Haddox, Susan E. "Is There a 'Biblical Masculinity'? Masculinities in the Hebrew Bible." Word and World 36 (2016): 5-14.

36 Rodd, "Psalms," 400. 
Holladay, William L. A Concise Hebrew and Aramaic Lexicon of the Old Testament. Leiden: Brill, 1971.

Jüngling, Hans-Winfried. "Psalms." Pages 779-859 in The International Bible Commentary: A Catholic and Ecumenical Commentary for the Twenty-first Century. Edited by William R. Farmer. Collegeville, PA: Liturgical, 1998.

Kimilike, Lechion, P. Poverty in the Book of Proverbs: An African Transformational Hermeneutic of Proverbs on Poverty. Bible and Theology in Africa 7. New York, NY: Peter Lang, 2008.

Magesa, Laurenti. Meeting of the Pan-African Seminar on Religion and Poverty, Ocho Rios, Jamaica in 2003.

Masenya, Madipoane J. In the School of Wisdom: An Interpretation of Some Old Testament Proverbs in a Northern Sotho Context. Unpublished M.A. Dissertation. Pretoria: University of South Africa, 1989.

Masenya (Ngwan'a Mphahlele), Madipoane. How Worthy is the Woman of Worth? Rereading Proverbs31:10-31 in African-South Africa. Bible and Theology in Africa 4. New York: Peter Lang, 2004.

"A Literary Figure or Patriarchal Reality? Reflections on the 'ěšet hayil in Light of Depictions of Womanhood from Selected Yoruba and Sotho Proverbs." Verbum et Ecclesia 39 (2018), a1861. https://doi.org/10.4102/ve.v39i1.1861. . “An Eco(bosadi) Reading of Psalm 127." Pages 109-122 in The Earth Story in the Psalms and the Prophets. Edited by Norman C. Habel and Shirley Wurst. Earth Bible 4. Sheffield: Sheffield Academic, 2001. . "The Use of the Bible Regarding Poverty in African-South African Pentecostal Settings: A Bosadi (Womanhood) Approach." Pages 152-165 in Religion and Poverty: Pan African Perspectives. Edited by Peter P. Paris. Durham, NC: Duke University Press, 2009. https://doi. org/10.1215/9780822392309-008. "Ruling from Their Graves? Reading Naomi within the African ReligioCultural Context." Pages 3-14 in The Five Scrolls. Edited by Athalya BrennerIdan, Gale A. Yee and Archie C. C. Lee. Texts @ Contexts 6. London: T\&T Clark, 2018. https://doi.org/ 10.5040/9780567678959.ch-001.

Meyers, Carol, "Everyday Life: Women in the Period of the Hebrew Bible." Pages 244251 in The Women's Bible Commentary. Edited by Carol A. Newsom and Sharon H. Ringe. Louisville, KY: Westminster John Knox, 1992.

Matsepe, Oliver K. Kgati ya Moditi. Pretoria: Van Schaik, 1974.

Mbiti, John S. African Religions and Philosophy. London: Heinemann, 1969.

McCann, J. Clinton, Jr. "The Book of Psalms.” Pages 641-1279 in The New Interpreters Bible, Vol. IV. Edited by Leander E. Keck. Nashville, TN: Abingdon, 1996.

Mwaura, Philomena N. "The Old Testament in the Nabii Christian Church of Kenya." Pages 165-169 in Interpreting the Old Testament in Africa: Papers from the International Symposium on Africa and the Old Testament in Nairobi, October 1999. Edited by Mary N. Getui, Knut Holter and Victor Zinkuratire. Bible and Theology in Africa 2. New York, NY: Peter Lang, 2001.

Nkesiga, S. B. Virtuous Living: Toward an African Theology of Wisdom in the Context of the African Renaissance. Ph.D. Thesis. Port Elizabeth: Nelson Mandela Metropolitan University, 2005.

Oduyoye, Mercy A. Daughters of Anowa: African Women and Patriarchy. Maryknoll, NY: Orbis, 1995. 
Olojede, Funlola. “(Un)popular Images of Women in Yoruba Popular Culture: A Quest for Human Dignity." Pages 187-205 in Sacred Selves: Essays on Gender, Religion and Popular Culture. Edited by Juliana Claassens and Sylvia Viljoen. Cape Town: Griffel, 2012.

Rakoma, J. R. D. Marema-ka-Dika Tša Sesotho sa Leboa. Pretoria: Van Schaik, 1971. Ratele, Kopano. Liberating Masculinities. Cape Town: HSRC, 2016.

Rodd, Cyril S. "Psalms." Pages 355-404 in The Oxford Bible Commentary. Edited by John Barton and John Muddiman. Oxford: Oxford University Press, 2001.

Stuhlmueller, Carroll. "Psalms." Pages 433-494 in Harper's Bible Commentary. Edited by James Luther Mays. San Francisco, CA: Harper \& Row, 1988.

Tewoldemedhim, Habtu, et al., "Psalms." Pages 605-746 in Africa Bible Commentary: A One-Volume Commentary Written by 70 African Scholars. Edited by Tokunboh Adeyemo. Nairobi: Word Alive, 2006.

Prof Madipoane Masenya (Ngwan'a Mphahlele), Department of Biblical and Ancient Studies, University of South Africa, P.O. Box 392, 0003 University of South Africa, South Africa, Email masenmj@unisa.ac.za. ORCID: https://orcid.org/0000-0001-7373-2454. 